\title{
硝酸カリウム配合歯磨剤による象牙質知覚過敏抑制効果
}

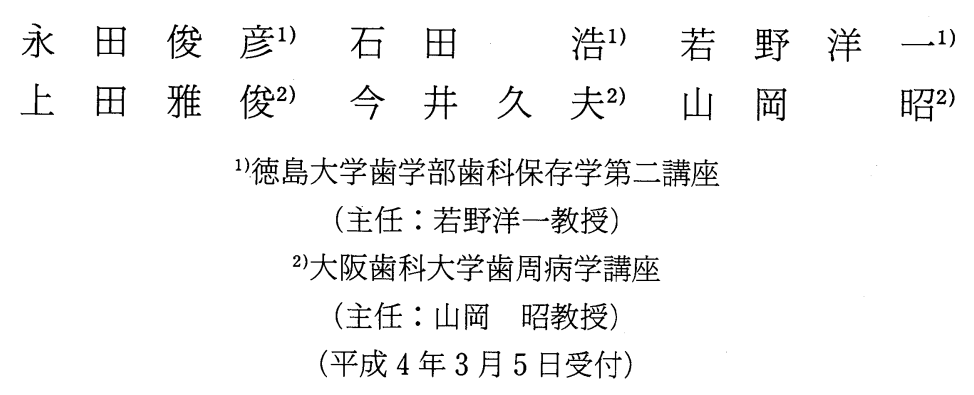

\section{Clinical Evaluation of Potassium Nitrate Dentifrice for Dentinal Hypersensitivity}

\author{
Toshihiko NAGATA ${ }^{1)}$, Hiroshi ISHIDA ${ }^{1)}$, Yoichi WAKANO ${ }^{1)}$, \\ Masatoshi $\mathrm{UEDA}^{2)}$, Hisao $\mathrm{IMAI}^{2)}$ and Akira YAMAOKA ${ }^{2)}$ \\ ${ }^{1)}$ Department of Periodontology and Endodontology, School of Dentistry, Tokushima University \\ 3-18-15, Kuramoto, Tokushima 770, Japan \\ (Head : Prof. Yoichi WAKANO) \\ ${ }^{2}$ Department of Periodontology, Osaka Dental University \\ 1-5-31, Ohtemae, Chuo-ku, Osaka 540, Japan
}

(Head : Prof. Akira YAMAOKA)

The effectiveness of $5 \%$ potassium nitrate dentifrice as a daily home treatment for dentinal hypersensitivity was evaluated in a double-blind study using 74 subjects who claimed dentinal hypersensitivity. Hypersensitivity levels in affected teeth were assessed by two quantifying methods, one using a tactile stimulus and the other a cold air stimulus, and by subjective response. The results of these three methods of assessment indicated that potassium nitrate dentifrice significantly desensit- ized hypersensitive teeth. The reaction to the cold air stimulus and the subjective symptoms both decreased markedly within 2 weeks, and the tactile induced-pain decreased within 4 weeks. The therapeutic response increased continuously during the 12 week study period. No side effects were observed in the oral tissues of the subjects during the experimental period. These results indicate that $5 \%$ potassium nitrate dentifrice is useful as a daily home treatment material.

Key words : Dentinal hypersensitivity, Potassium nitrate dentifrice, Clinical test

要旨：本邦における 5\% 硝酸カリウム配合歯磨剤の象牙質知覚過敏に対する臨床効果を調べるために, 74 名の 被験者を対象に 37 名を試験群, 37 名を対照群として, 擦過刺激試験, 冷気刺激試験, 自覚評価の 3 種類の診查項 目について二重盲検法を行なった。試験群すなわち硝酸カリウム配合歯磨剤使用群では, すべての診査項目におい て反応や症状の改善または消失が著明に認められた。その診査数值の減少率は使用後 4 週, 8 週, 12 週において, すべて対照群よりも有意に高かった。試験群で症状が改善した被験者数は，2 週目で $44 \%, 4$ 週目以降では $80 \%$ を 越え, 症状が消失した被験者は， 8 週目で $42 \% ， 12$ 週目で $56 \%$ に達した。また，とくに問題となるような副作用 は認められなかった。これらの結果から，5\% 硝酸カリウム配合歯磨剂が, 象牙質知覚過敏の症状緩和に適した歯 磨剤であることが明らかとなった。

索引用語：象牙質知覚過敏, 硝酸カリウム配合歯磨剤, 臨床試験 


\section{緒言}

象牙質知覚過敏は, エナメル質やセメント質による 被覆を欠いた象牙質面に, 機械的, 温度的, 化学的刺 激が加わったときの一過性の電撃的痛みをさし, また 自発痛のみられないことを特徵とする1)。この痛みは， 露出した象牙質の感覚が方進することによって引き起 こされ, その程度は各人各様で, 限局された強い痛み を訴えるものから単なる不快感である場合など一様で はない。象牙質知覚過敏に対する治療法には, 薬物塗 布法 ${ }^{2}$, イオン導入法3)などの医師側からの治療と, 薬 物配合歯磨剂を用いた患者自身による方法 ${ }^{4}$ が挙げら れる。これらはいずれも, 露出した象牙細管開口部を 物理的に被覆, 狭窄あるいは閉塞することによって, 象牙質知覚過敏の抑制を期待する治療方法である。

歯磨剤による方法は, 日常生活の中で行える簡便で 負担の少ない方法であるとともに, 象牙質知覚過敏症 状発現の予防にも適用される。本邦では従来より, 乳 酸アルミニウム ${ }^{5)}$, 塩化アルミニウム ${ }^{6)}$, 塩化ストロン チウム7などの薬用成分を含んだ知覚過敏用歯磨剂が 用いられている。欧米でも最近 10 年の間に, 種々の成 分を含む歯磨剤が開発，販売され，とりわけ硝酸カリ ウムを含む歯磨剂は優れた知覚過敏抑制効果をもつこ とから，その有用性についての高い評価が報告されて いる ${ }^{8 \sim 11)}$ 。一方, 本邦での硝酸カリウム含有歯磨剤の象 牙質知覚過敏に対する使用効果についての情報は, 現 在のところ見当たらない。今回, 我々は, その効果を 調查する機会を得て, 本歯磨剤が象牙質知覚過敏を訴 える本邦の患者に対しても有効であるという結果を得 た。

\section{材料および方法}

\section{1. 被 験 者}

表 1 に示すように, 被験者には徳島大学歯学部附属 病院あるいは大阪歯科大学附属病院歯周病科を受診 し, 歯䅡部に象牙質知覚過敏を訴え, かつ本試験の開

表 1

\begin{tabular}{ccccc}
\hline 施 & 設 & 男 & 女 & 合計 \\
\hline 徳島大学歯学部附属病院 & 15 & 22 & 37 \\
大阪歯科大学附属病院 & 16 & 21 & 37 \\
\multicolumn{2}{c}{ 合 計 } & 31 & 43 & 74 \\
\hline
\end{tabular}

始に先立ち被験者となることを同意した年齢 18～69 歳の患者 74 名（男性 31 名，女性 43 名）が選ばれた。 被験歯数は合計 243 本,一人平均 3.3 本であった。な お，問診時に歯磨剤や口腔粘膜治療剤などにアレル ギーの既往がある場合，あるいは被験歯が部分床義歯 の鉤歯として利用されていたり，エナメル質の亀裂や 進行したう蝕が被験歯に認められる場合には, これら を被験者の対象から除外した。

\section{2. 試験期間および診査時期}

試験実施期間は平成 3 年 2 月から平成 3 年 9 月まで の約 7 か月間とした。各被験者の診査時期は, Silverman ${ }^{11)}$ の報告と同様に, 試験開始時, 2 週, 4 週, 8 週，および 12 週目とし，それぞれの診査結果を評価 用紙に記載した。

\section{3. 試験材料および使用方法}

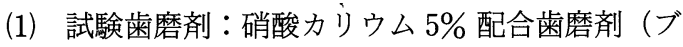
ロックドラッグ社, 米国)

（2）対照歯磨剤：試験歯磨剤から硝酸カリウムを除 いた歯磨剈（ブロックドラッグ社，米国）

(3) 歯ブラシ：パイコペイソフテックス（ブロック ドラッグ社，米国)

(4) 砂時計：1 分計 (佐藤計量器社, 東京)

以上の器具と与えられた試験歯磨剤あるいは対照歯 磨剂を用いて，1 日 2 回(朝, 夜), 12 週間ブラッシン グをするように，被験者に指示した。歯磨剤の 1 回の 使用量は約 $2 \mathrm{~g}$ (チューブからの押し出しの長さ約 3 $\mathrm{cm}$ 分) とし, ブラッシング方法は被験者が通常行って いる方法で，とくに規定はしなかった。また 1 回のブ ラッシング時間は少なくとも 1 分以上とするように指 示した。

\section{4. 試験方法}

本試験は, 試験群と対照群とを比較する二重盲検法 によって実施された。すなわち，被験者および担当医 師の双方とも，試験歯磨剤あるいは対照歯磨剤のいず れが配布されたかが分からないようにし，これらは予 め無作為操作を経て割り付けられ一連の番号が付され た後, 若い番号順に被験者に渡された。すべての試験 が終了した後, 試験群と対照群の番号別割付表の入っ た封筒を開封し, 各症例がどちらの群に属していたか を確認して,それぞれを 2 群に分けた。

\section{5. 診查方法および判定基準}

(1) 擦過痛，(2) 冷気痛，(3) 自覚評価の 3 点につい て，それぞれ(4)に示すような判定基準を設定した。診 查に際し, 被験歯に対して最初に擦過刺激試験，引き 
表 2 被験者背景

\begin{tabular}{|c|c|c|c|c|c|}
\hline & 景 因子 & 試験群 & 対照群 & 合計 & 検定結果 \\
\hline \multirow{3}{*}{ 性 別 } & 男 & 17 & 14 & 31 & \multirow{3}{*}{ N.S.* } \\
\hline & 女 & 20 & 23 & 43 & \\
\hline & 合 計 & 37 & 37 & 74 & \\
\hline \multirow{7}{*}{$\begin{array}{l}\text { 年 齢 } \\
\text { (歳) }\end{array}$} & $\sim 30$ & 5 & 3 & 8 & \multirow{7}{*}{ N.S.* } \\
\hline & $31 \sim 40$ & 4 & 7 & 11 & \\
\hline & $41 \sim 50$ & 11 & 13 & 24 & \\
\hline & $51 \sim 60$ & 14 & 10 & 24 & \\
\hline & $61 \sim$ & 3 & 4 & 7 & \\
\hline & 合 計 & 37 & 37 & 74 & \\
\hline & 平均土標準偏差 & $46.4 \pm 11.7$ & $47.0 \pm 11.4$ & $46.7 \pm 11.4$ & \\
\hline $\begin{array}{c}\text { 被験歯数 } \\
\text { (本/人) }\end{array}$ & 平均土標準偏差 & $3.1 \pm 1.6$ & $3.5 \pm 1.8$ & $3.3 \pm 1.7$ & N.S.** \\
\hline
\end{tabular}

N.S. : Not significant

$*: x^{2}$ 検定

** : Mann-Whitney $U$ 検定

続き冷気刺激試験を行なうこととした。また測定值の 誤差を少なくするために， 1 施設 2 名の熟練した歯科 医師によって以下の診査が行われた。

（1） 擦過痛：歯頝部に一定の圧力を加えることが可 能な深針（\#16イープルプローブ, Vine Valley Research 社, 米国)を用いて, 歯面に対して $40 \mathrm{~g}$ の一 定圧で直角に擦過した。

(2) 冷気痛: 隣接歯をガーゼ等で被って被験歯から 隔離し, 被験歯の唇側歯䅡部に圧搾空気を 1 秒間吹き つけた。

(3) 自覚評価：担当医師が問診を行なうことによ り, 被験者自身の日常生活での過敏状態を評価した。

（4）判定基準: 試験開始時, 2 週, 4 週, 8 週, 12 週 目に行なった擦過および冷気刺激試験, ならびに自覚 評価を, 以下に示す 4 段階のスコアによって評価した。

不快感や痛みを感じない $\cdots 0$

不快だが強い不快感や痛みではない …………1

刺激中に強い不快感や痛みを感じる…………...2

刺激中も刺激中止後も強い不快感や痛みを感じる

この 4 段階評価形式は, Clark と Troullousの方 法 ${ }^{12}$ に準じ,一部を改変して作成した。また, 被験者の 選定にあたっては, 擦過あるいは冷気刺激試験でスコ ア 2 以上の被験歯をもつことを必要条件とし, 自覚評 価については症状の改善と消失についても検討した。 なお，ここで言う改善とは試験開始時に比べ不快感や 痛みの程度が少なくなること, すなわちスコアの減少
を意味し, 消失とは試験開始時に不快感や痛みがあっ た被験者が，その後不快感や痛みを全く訴えなくなる こと，すなわちスコアが 0 になることを意味するもの と定義した。

\section{6. 安全性の評価}

担当医師は，試験期間中，被験者に対して問診を行 なうと同時に，歯面や煩粘膜などを肉眼的に精査する ことによって, 歯磨剤の安全性について評価した。

\section{7. 脱落および中止例の取り扱い}

被験者が試験途中で, 来院できなくなった場合には, 脱落例として除外した。また, 被験者に副作用が生じ, 試験の継続ができなくなった場合や，試験者が試験中 止を希望したり, 担当医師が試験の中止が必要である と認めた場合には，これを試験中止例とした。

\section{8. 統計解析方法}

データの解析には, $\chi^{2}$ 検定, Fisher の直接確率計算 法および Mann-Whitney $U$ 検定のいずれかが選択さ れた ${ }^{13)}$ 。なお，有意水準は 0.05 とした。

\section{結 果}

\section{1. 被験者背景}

性別，年齢および被験者一人あたりの過敏歯数につ いて, 試験群と対照群との間に偏りがないかどうかを 調べたのが表 2 である。試験群と対照群との間に, 男 女間の差, 年齢による差, および被験歯数の差は, 何 ら認められなかった。 


\section{2. 試験開始時の知覚過敏の程度}

表 3 に示したように, 試験開始時の擦過刺激, 冷気 刺激, ならびに自覚評価において, 試験群と対照群と の間に有意な偏りは認められなかった。

\section{3. 擦過刺激}

擦過刺激に対する平均スコアの変化を表 4 に示し た。試験群では， 2 週目 $18.9 \% ， 4$ 週目 $48.9 \% ， 8$ 週

表 3 試験開始時の知覚過敏の程度

\begin{tabular}{cccc}
\hline & 試験群 & \multicolumn{1}{c}{ 対照群 } & \\
\cline { 2 - 3 } & $\begin{array}{c}\text { 平均スコア } \\
\text { 土標準偏差 }\end{array}$ & $\begin{array}{c}\text { 平均スコア } \\
\text { 土標準偏差 }\end{array}$ & \\
\hline 擦過刺激 & $1.80 \pm 0.45$ & $1.62 \pm 0.63$ & N.S. \\
冷気刺激 & $2.16 \pm 0.52$ & $2.12 \pm 0.49$ & N.S. \\
自覚評価 & $2.19 \pm 0.40$ & $2.08 \pm 0.49$ & N.S. \\
\hline
\end{tabular}

N.S. : Not significant

**: Mann-Whitney $U$ 検定
目 $74.3 \%, 12$ 週目 $81.0 \%$ ，それぞれスコアが減少し た。一方, 対照群では， 2 週目 $11.1 \% ， 4$ 週目 $21.6 \%$, 8 週目 $29.0 \%, 12$ 週目 $35.2 \%$ の減少率に過ぎなかっ た。平均スコアは, 試験群, 対照群ともに試験開始時 より経時的に減少したが，その減少率は 2 週目を除く それ以後のすべての診查時点 $(4,8,12$ 週目) で, 試 験群の方が対照群よりも有意に高かった。例えば試験 開始 4 週目において, 試験群ではすでに対照群の約 2 倍の減少率が認められた。

\section{4. 冷気刺激}

表 5 に示したように, 冷気刺激の場合, 試験群では, 2 週目 $25.8 \% ， 4$ 週目 $51.4 \% ， 8$ 週目 $71.4 \% ， 12$ 週 目 $79.7 \%$ のスコアの減少率を示した。一方, 対照群で は，2 週目 $11.8 \% ， 4$ 週目 $23.6 \% ， 8$ 週目 $31.1 \% ， 12$ 週目 $34.4 \%$ の減少率にとどまった。擦過刺激試験と同 様, 平均スコアは両群ともに経時的に減少した。しか しながら，試験群の減少率は全診査時点において対照

表 4 擦過刺激

\begin{tabular}{|c|c|c|c|c|c|c|c|}
\hline & & 試 験 群 & & & 照 & & \\
\hline & $\mathrm{N}^{*}$ & $\begin{array}{c}\text { 平均スコア } \\
\text { 土標準偏差 }\end{array}$ & 減少率 & $\mathrm{N}^{*}$ & $\begin{array}{c}\text { 平均スコア } \\
\text { 土標準偏差 }\end{array}$ & 減少率 & 検定結果** \\
\hline $\begin{array}{l}\text { 試験開始時 } \\
2 \text { 週 目 }\end{array}$ & 29 & $\begin{array}{l}1.80 \pm 0.45 \\
1.46 \pm 0.59\end{array}$ & $18.9 \%$ & 32 & $\begin{array}{l}1.62 \pm 0.63 \\
1.44 \pm 0.71\end{array}$ & $11.1 \%$ & N.S. \\
\hline $\begin{array}{l}\text { 試験開始時 } \\
4 \text { 週 目 }\end{array}$ & 29 & $\begin{array}{l}1.80 \pm 0.45 \\
0.92 \pm 0.58\end{array}$ & $48.9 \%$ & 32 & $\begin{array}{l}1.62 \pm 0.63 \\
1.27 \pm 0.68\end{array}$ & $21.6 \%$ & $p<0.01$ \\
\hline $\begin{array}{l}\text { 試験開始時 } \\
8 \text { 週 目 }\end{array}$ & 28 & $\begin{array}{l}1.79 \pm 0.46 \\
0.46 \pm 0.52\end{array}$ & $74.3 \%$ & 32 & $\begin{array}{l}1.62 \pm 0.63 \\
1.15 \pm 0.64\end{array}$ & $29.0 \%$ & $p<0.01$ \\
\hline $\begin{array}{l}\text { 試験開始時 } \\
12 \text { 週 目 }\end{array}$ & 28 & $\begin{array}{l}1.79 \pm 0.46 \\
0.34 \pm 0.50\end{array}$ & $81.0 \%$ & 32 & $\begin{array}{l}1.62 \pm 0.63 \\
1.05 \pm 0.62\end{array}$ & $35.2 \%$ & $p<0.01$ \\
\hline
\end{tabular}

$\mathrm{N}^{*}$ : 被験者数（人）

N.S. : Not significant

**: Mann-Whitney $U$ 検定

表 5 冷気刺激

\begin{tabular}{|c|c|c|c|c|c|c|c|}
\hline & \multicolumn{3}{|c|}{ 試 験 群 } & \multicolumn{3}{|c|}{ 対＼cjkstart照＼cjkstart群 } & \multirow[b]{2}{*}{ 検定結果 ** } \\
\hline & $\mathrm{N}^{*}$ & $\begin{array}{c}\text { 平均スコア } \\
\text { 土標準偏差 }\end{array}$ & 減少率 & $\mathrm{N}^{*}$ & $\begin{array}{c}\text { 平均スコア } \\
\text { 土標準偏差 }\end{array}$ & 減少率 & \\
\hline $\begin{array}{l}\text { 試験開始時 } \\
2 \text { 週 }{ }^{\text {目 }}\end{array}$ & 36 & $\begin{array}{l}2.17 \pm 0.52 \\
1.61 \pm 0.60\end{array}$ & $25.8 \%$ & 37 & $\begin{array}{l}2.12 \pm 0.49 \\
1.87 \pm 0.65\end{array}$ & $11.8 \%$ & $p<0.05$ \\
\hline $\begin{array}{l}\text { 試験開始時 } \\
4 \text { 週 目 }\end{array}$ & 37 & $\begin{array}{l}2.16 \pm 0.52 \\
1.05 \pm 0.62\end{array}$ & $51.4 \%$ & 37 & $\begin{array}{l}2.12 \pm 0.49 \\
1.62 \pm 0.66\end{array}$ & $23.6 \%$ & $p<0.01$ \\
\hline $\begin{array}{l}\text { 試験開始時 } \\
8 \text { 週 } \quad \text { 目 }\end{array}$ & 36 & $\begin{array}{l}2.17 \pm 0.52 \\
0.62 \pm 0.53\end{array}$ & $71.4 \%$ & 37 & $\begin{array}{l}2.12 \pm 0.49 \\
1.46 \pm 0.69\end{array}$ & $31.1 \%$ & $p<0.01$ \\
\hline $\begin{array}{l}\text { 試験開始時 } \\
12 \text { 週 目 }\end{array}$ & 36 & $\begin{array}{l}2.17 \pm 0.52 \\
0.44 \pm 0.52\end{array}$ & $79.7 \%$ & 37 & $\begin{array}{l}2.12 \pm 0.49 \\
1.39 \pm 0.72\end{array}$ & $34.4 \%$ & $p<0.01$ \\
\hline
\end{tabular}

$\mathrm{N}^{*}$ : 被験者数（人）

** : Mann-Whitney $U$ 検定 
表 6 自覚評価

\begin{tabular}{|c|c|c|c|c|c|c|c|}
\hline & \multicolumn{3}{|c|}{ 試＼cjkstart験＼cjkstart群 } & \multicolumn{3}{|c|}{ 対 照 群 } & \multirow[b]{2}{*}{ 検定結果 ** } \\
\hline & $\mathrm{N}^{*}$ & $\begin{array}{c}\text { 平均スコア } \\
\text { 土標準偏差 }\end{array}$ & 減少率 & $\mathrm{N}^{*}$ & $\begin{array}{c}\text { 平均スコア } \\
\text { 土標準偏差 }\end{array}$ & 減少率 & \\
\hline $\begin{array}{l}\text { 試験開始時 } \\
2 \text { 週 }{ }^{-1} \text { 目 }\end{array}$ & 36 & $\begin{array}{l}2.19 \pm 0.40 \\
1.72 \pm 0.62\end{array}$ & $21.5 \%$ & 37 & $\begin{array}{l}2.08 \pm 0.49 \\
1.89 \pm 0.61\end{array}$ & $9.1 \%$ & $p<0.05$ \\
\hline $\begin{array}{l}\text { 試験開始時 } \\
4 \text { 週 目 }\end{array}$ & 37 & $\begin{array}{l}2.19 \pm 0.40 \\
1.14 \pm 0.59\end{array}$ & $47.9 \%$ & 37 & $\begin{array}{l}2.08 \pm 0.49 \\
1.73 \pm 0.65\end{array}$ & $16.8 \%$ & $p<0.01$ \\
\hline $\begin{array}{l}\text { 試験開始時 } \\
8 \text { 週 } \quad \text { 目 }\end{array}$ & 36 & $\begin{array}{l}2.19 \pm 0.40 \\
0.69 \pm 0.67\end{array}$ & $68.5 \%$ & 37 & $\begin{array}{l}2.08 \pm 0.49 \\
1.57 \pm 0.65\end{array}$ & $24.5 \%$ & $p<0.01$ \\
\hline $\begin{array}{l}\text { 試験開始時 } \\
12 \text { 週 目 }\end{array}$ & 36 & $\begin{array}{l}2.19 \pm 0.40 \\
0.56 \pm 0.70\end{array}$ & $74.4 \%$ & 37 & $\begin{array}{l}2.08 \pm 0.49 \\
1.43 \pm 0.77\end{array}$ & $31.3 \%$ & $p<0.01$ \\
\hline
\end{tabular}

表 7 被験者の自覚症状の改善に関する比較分析

\begin{tabular}{|c|c|c|c|c|c|}
\hline & \multicolumn{2}{|c|}{ 試験群 } & \multicolumn{2}{|c|}{ 対照群 } & \multirow{2}{*}{ 検定結果* } \\
\hline & $\mathrm{N}^{*}$ & 改善人数 & $\mathrm{N}^{*}$ & 改善人数 & \\
\hline 2 週目 & 36 & $16(44 \%)$ & 37 & $6(16 \%)$ & $p<0.01$ \\
\hline 4 週目 & 37 & $30(81 \%)$ & 37 & $11(30 \%)$ & $p<0.01$ \\
\hline 8 週目 & 36 & $32(89 \%)$ & 37 & $16(43 \%)$ & $p<0.01$ \\
\hline 12 週目 & 36 & $32(89 \%)$ & 37 & $18(49 \%)$ & $p<0.01$ \\
\hline
\end{tabular}

群のそれよりも有意に高く, 試験開始 2 週目にして試 験群では対照群の約 2 倍の減少率が認められた。

\section{5. 自覚評価}

自覚評価についての平均スコアの経時的変化を表 6 に示した。試験群では，2 週目 $21.5 \% ， 4$ 週目 $47.9 \%$, 8 週目 $68.5 \%, 12$ 週目 $74.4 \%$ と, スコアの減少がみ られたのに比べ, 対照群では, 2 週目 9.1\%，4 週目 $16.8 \% ， 8$ 週目 $24.5 \% ， 12$ 週目 $31.3 \%$ の減少率を示 した。その減少率は全診査時点において, 試験群の方 が対照群よりも有意に高く, 2 週目で約 2 倍, 4 週目 で約 3 倍の減少率を示した。

次に, 自覚症状が改善した被験者, あるいは消失し た被験者の人数を調べることによって, 試験群と対照 群とを比較した。表 7 に示したように, 試験群では, 試験開始後 2 週目で,すでに半数近くに相当する 16 名 (44\%)の被験者に自覚症状の改善がみられ，4 週目で 30 名 (81\%)，12 週目で 32 名 (89\%) とその数が増加 した。一方, 対照群では, 2 週目で 6 名(16\%)， 4 週 目で 11 名 $(30 \%), 12$ 週目で 18 名 $(49 \%)$ と, その数 は半数にも達しなかった。これらを比べた場合, すべ ての検查時点で試験群の方が対照群よりも有意に高い
表 8 被験者の自覚症状の消失に関する比較分析

\begin{tabular}{|c|c|c|c|c|c|}
\hline & \multicolumn{2}{|c|}{ 試験群 } & \multicolumn{2}{|c|}{ 対照群 } & \multirow{2}{*}{ 検定結果 } \\
\hline & $\mathrm{N}^{*}$ & 消失人数 & $\mathrm{N}^{*}$ & 消失人数 & \\
\hline 2 週目 & 36 & $1(3 \%)$ & 37 & $1(3 \%)$ & N.S. ${ }^{* * *}$ \\
\hline 4 週目 & 37 & $4(11 \%)$ & 37 & $1(3 \%)$ & N.S.*** \\
\hline 8 週目 & 36 & $15(42 \%)$ & 37 & $1(3 \%)$ & $p<0.01^{*}$ \\
\hline 12 週目 & 36 & $20(56 \%)$ & 37 & $4(11 \%)$ & $p<0.01^{*}$ \\
\hline
\end{tabular}

$\mathrm{N}^{*}$ : 被験者数（人)

N.S. : Not significant

$*: x^{2}$ 検定

*** : Fisher の直接確率計算法

自覚症状の改善を示していた。自覚症状の消失は, 表 8 に示したように，2 週および 4 週目までは試験群, 対照群ともにごく少数の被験者にしか認められず，双 方に有意な差はなかったが, 試験群では 8 週目で 15 名 (42\%)，12 週目で 20 名 $(56 \%)$ と，約半数の被験者に 自覚症状が消失した。一方, 対照群では 12 週目で 4 名 （11\%）消失したのが最高であった。 8 およ゙ 12 週目 では, 試験群と対照群との間にそれぞれ有意な差が認 められた。

\section{6. 安全 性}

2 週, 4 週, 8 週, 12 週目の各時点での診査の結果, 74 名のうち 1 名の被験者が 4 週目に口腔粘膜の違和 感を訴え, 実際, 前歯部口腔粘膜に軽度の発赤が認め られた。この症例では, 本人の希望により 8 週と 12 週 目の試験を中止した。他の 73 名の被験者については, 試験期間中，何ら障害は認められなかった。 


\section{考察}

象牙質知覚過敏の予防や治療には，プラークコント ロールが重要である ${ }^{4)}$ 。知覚過敏による痛みのために ブラッシングに適切さを欠くようになった場合，プ ラークが歯䅡部に蓄積し，象牙細管開口部が脱灰され て,さらに過敏症状が進行するという悪循環が生じや すい。このような場合, 十分なプラークコントロール を行なうことによって, 過敏症状が改善する例も多い。 しかしながら, 本研究で適用したスコア 2 以上の症状 を示す象牙質知覚過敏例では, 単にプラークコント ロールを実践するだけでは，症状の緩和は十分に図れ ないと考えられる。本試験の対照群においても, 擦過 刺激, 冷気刺激, 自覚評価にスコアの減少は認められ たが，いずれも減少率 $30 \%$ 程度 (12 週) で，これは試 験群の減少率約 80\%（12 週）に比べると有意に少ない 值であった。

$5 \%$ 硝酸カリウム配合歯磨剤の有効性については, 欧米ですでに報告されている。Hodosh ${ }^{8)}$ は硝酸カリウ ムの飽和溶液， $15 \% ， 10 \%, 5 \%, 2 \%, 1 \%$ 溶液および $10 \%$ ペーストを患者に使用し, いずれの場合において も効果があり，しかも副作用もなかったことを報告し ている。Tarbet ら ${ }^{9} は$ 冷気および電気的刺激を応用し た試験によって二重盲検法を行ない, 硝酸カリウム配 合歯磨剤の効果は使用後 1 週間で現われ，4 週間後で は, 試験群の $92 \%$ に知覚過敏の改善（対照群では 21\%）が認められたと述べている。また彼らは同様の 方法を用いて，5\% 硝酸カリウム，10\% 塩化ストロン チウム, $2 \%$ クエン酸ナトリウム, および $1.4 \%$ ホルム アルデヒドをそれぞれ配合した歯磨剤を比較した場 合, 硝酸カリウムの効果が一番優れていたと報告して

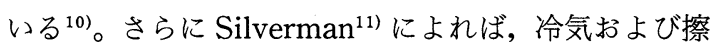
過による疼痛誘発試験において, 硝酸カリウム配合歯 磨剤が対照歯磨剤に比へ，有意に痛みを軽減すること が明らかにされている。これらの報告は，いずれも欧 米での硝酸カリウム配合歯磨剤の有用性を示したもの である。

今回, 我久は，本邦におけるその有用性を二重盲検 法によって検討した。試験に先立ち, 被験者の性別, 年齢, 過敏歯数, 知覚過敏の程度には, 試験群と対照 群との間に有意差は認められなかった(表 1〜3)。これ は, 歯磨剤の割付が公平に行なわれたことを示す結果 であると考えられる。擦過および冷気刺激試験では,
4 週目で約 $50 \%$ のスコア減少率，8～12 週目では $70 \sim 80 \%$ のスコア減少率を示し，これらは対照群の減 少率に比べ有意に高い数值であった（表 4,5$)$ 。自覚評 価においても，スコアの減少率は擦過および冷気刺激 試験と同様の推移を示し(表 6 ), 試験群では 2 週目で $44 \%$ の被験者が過敏症状の改善を自覚した。さらに本 歯磨剂を継続使用することにより 4〜12 週目で $80 \%$ 以上の被験者に改善がみられ，その効果が増大した(表 7 )。また, 症状が完全に消失した被験者は 12 週目で $56 \%$ に達した（表 8 )。これらの数値の一部は, Silverman ${ }^{11}$ が同様の硝酸カリウム配合歯磨㓮の効果 について報告した数值と酷似している。例えば, 12 週 目のスコア減少率は, 冷気刺激試験 $78 \%$, 自覚評価 75\%であったという彼の報告に対し，我々の結果は， 冷気刺激 $80 \%$, 自覚評価 $74 \%$ （表 5，6）であり，これ らはきわめて近似した数值を示していた。このように 本歯磨剤は，欧米人，日本人にかかわらず同様の知覚 過敏抑制効果を有していることが明らかとなった。一 方, 本歯磨剤の安全性については, 被験者 74 名中 1 名 に口腔粘膜の軽度の発赤が認められたが, 他の 73 名に ついては，歯磨剤使用による障害は何ら認められな かった。

以上の結果は，象牙質知覚過敏を対象に開発された 本歯磨剂が日本人に対しても有効であり，一般家庭で 安心して用いられる歯磨剤であることを示すものであ る。

\section{結 論}

$5 \%$ 硝酸カリウム配合歯磨剤の象牙質知覚過敏に対 する臨床効果について，74名の被験者を対象に二重盲 検法を行って検討し，以下のような結果を得た。

1）試験群の擦過刺激に対するスコアの減少率は, $2 ， 4 ， 8 ， 12$ 週目でそれぞれ $19 ， 49 ， 74 ， 81 \%$ と経時 的な増加を示した。これらの数值は，4 週目以降の対 象群の減少率よりも有意に高い值であった。

2) 試験群の冷気刺激に対するスコアの減少率は, $2 ， 4 ， 8 ， 12$ 週目でそれぞれ $26,51 ， 71 ， 80 \%$ と経時 的な増加を示した。これらの数値は対照群に比較して, すべての評価時点で有意に高い值であった。

3）試験群の自覚評価に対するスコアの減少率は, $2 ， 4 ， 8 ， 12$ 週目でそれぞれ $22 ， 48 ， 69 ， 74 \%$ と経時 的な増加を示した。これらの数值は対照群に比較して, すべての評価時点で有意に高い值であった。 
4）試験群の場合，みずから過敏症状が改善したと 認めた被験者は，2 週目で $44 \% ， 4$ 週目以降 $80 \%$ を越 え,また, 過敏症状が消失した被験者は, 8 週目で $42 \%, 12$ 週目で $56 \%$ に達した。これらの数值は, 対照 群に比較して有意に高い值であった。

5）とくに問題となるような副作用は認められな かった。

以上の結果, $5 \%$ 硝酸カリウム配合歯磨剤は本邦に おいても象牙質知覚過敏の症状緩和に適した歯磨剂で あることが明らかとなった。

\section{文献}

1）山岡 昭，中静 正，青野正男，中村治郎，村井正 大, 鴨井久一, 長谷川紘司, 石川 烈：歯周病学事 典, 第 1 版, クインテッセンス出版, 東京, 1987, 272 .

2）若野洋一：薬物塗布法. 歯科ジャーナル，18：155159, 1983.

3）池田英治, 山本 寛, 砂川光宏, 須田英明, 砂田今 男：象牙質の感覚過敏に対するシュウ酸カリウム溶 液の効果について。 日歯保誌, $31 ： 1202-1209,1988$.

4) Rylander, H., Lindhe, J. and Rosling, B. : Causerelated periodontal therapy, Lindhe, J., Textbook of clinical periodontology, 2nd edition, Munksgaard, Copenhagen, 1985, 343-365.

5）米田栄吉, 庄司 茂, 佐々木俊明, 遠藤英昭, 堀内 博, 鈴木祐平, 山口郁夫：乳酸アルミニウム含有歯
磨剂による象牙質知覚過敏の抑制。日歯保誌，33： 1070-1077, 1990.

6）真鍋圭毅，吉田隆一，西脇 賞，吉田 剛，関根一 郎，向山嘉幸 : 塩化アルミニウム抢よび硫酸亜鉛含 有の象牙質知覚過敏症治療剤について. 日歯保誌, $34: 608-613,1991$.

7）内田昭次, 若野洋一, 福山, 修, 勝谷芳文, 三木隆 雄, 河合淳二, 和田 甫, 村西憲一, 山上紘志, 岩 山幸雄, 岡田 宏: 歯周病の外科的処置後に現れた 象牙質知覚過敏症侄対する塩化ストロンチウム配合 歯磨剤の臨床的効果. 日歯周誌, $22: 486-491,1980$.

8) Hodosh, M. : A superior desensitizer-potassium nitrate. J. Am. Dent. Assoc. 88 : 831-832, 1974.

9) Tarbet, W.J., Silverman, G., Stolman, J.M. and Fratarcangelo, P.A. : Clinical evaluation of a new treatment for dentinal hypersensitivity. J. Periodontol., 51:535-540, 1980.

10) Tarbet, W.J., Silverman, G., Fratarcangelo, P.A. and Kanapka, J.A. : Home treatment for dentinal hypersensitivity: A comparative study. J. Am. Dent. Assoc. $105:$ 227-230, 1982.

11) Silverman, G. : The sensitivity-reducing effect of brushing with a potassium nitrate-sodium monofluorophosphate dentifrice. Comp. Cont. Educ. Dent. $6: 131-136,1985$.

12) Clark, G.E. and Troullous, E.S. : Designing hypersensitivity clinical studies. Dent. Clin. North Am. 34:531-544, 1990.

13）市原清志：バイオサイエンスの統計学, 第 1 版, 南 江堂, 東京, 1991, 72-144.

\section{連絡先：}

徳島大学歯学部歯科保存学第二講座

于 770 徳島市蔵本町 3 丁目 $18-15$ 